\title{
Increased creatine demand during pregnancy in Arginine: Glycine Amidino- Transferase deficiency: a case report
}

\author{
Maria Grazia Alessandri ${ }^{1 *}$, Francesca Strigini ${ }^{2}$, Giovanni Cioni ${ }^{1,2}$ and Roberta Battini ${ }^{1,2}$
}

\begin{abstract}
Background: Creatine (Cr), an amino acid derivative, is one of the most important sources of energy acting as both a spatial and temporal energy buffer through its phosphorylated analogue phosphocreatine $(\mathrm{PCr})$ and creatine kinase (CK). Maternal $\mathrm{Cr}$ biosynthesis and metabolism seem to play an important role in pregnancy, as shown in preclinical and in healthy human pregnancy studies. Patients with Arginine:Glycine Amidino-Transferase deficiency (AGAT-d), due to the deficit of the first enzyme involved in $\mathrm{Cr}$ synthesis, are at a disadvantage due to their failure to synthesize $\mathrm{Cr}$ and their dependence on external intake, in contrast to normal subjects, where changes in $\mathrm{Cr}$ biosynthesis supply their needs.

We report the outcomes of a pregnancy in an AGAT-d woman, and the challenge we faced in managing her treatment with oral $\mathrm{Cr}$ to ensure optimal conditions for her fetus.

Case presentation: A 22-year-old AGAT-d woman referred to our Institute for the management of her first conception at 11 weeks of fetal gestational age. Sonographic monitoring at 20 w GA indicated a reduction of fetal growth, in particular of the head circumference that was below the $3^{\text {rd }}$ centile. Biochemical monitoring of $\mathrm{Cr}$ in biological fluids of the mother revealed a decline of the $\mathrm{Cr}$ concentrations, in particular in the urine sample, requiring prompt correction of the $\mathrm{Cr}$ dose. At 35 weeks of gestation the patient delivered a male infant, heterozygous for GATM mutation, with normal brain Cr levels; at one year the baby achieved typical developmental milestones.

Conclusions: This rare pregnancy demonstrates that Cr levels in the blood and urine of the mother with AGAT-d decreased since the first months of gestation. The increase of the $\mathrm{Cr}$ daily dose administered to the mother seems to have produced beneficial effects also on the fetus.
\end{abstract}

Keywords: Creatine deficiency, AGAT, Pregnancy

\section{Background}

$\mathrm{Cr}$ is synthesized in a two-step reaction, where the ratelimiting step is the Arginine: Glycine AmidinoTransferase (AGAT) reaction to form guanidinoacetic acid (GAA) from arginine and glycine; GAA is quickly converted to $\mathrm{Cr}$ by guanidinoacetate methyltransferase

\footnotetext{
* Correspondence: mg.alessandri@fsm.unipi.it

'Department of Developmental Neuroscience, IRCCS Stella Maris Foundation, Via dei Giacinti 2, 56128 Calambrone - Pisa, Italy

Full list of author information is available at the end of the article
}

(GAMT). AGAT deficiency (AGAT-d; MIM 602,360) causes the rarest inborn error of $\mathrm{Cr}$ deficiency syndromes [1, 2]. Chronic $\mathrm{Cr}$ supplementation at various dosages, ranging from $100 \mathrm{mg} / \mathrm{Kg} /$ day to $800 \mathrm{mg} / \mathrm{Kg} /$ day, restored brain $\mathrm{Cr}$ in all patients diagnosed so far and improved cognitive development and other clinical symptoms [2].

$\mathrm{Cr}$, an amino acid derivative, is one of the most important sources of energy due to its primary function as both a spatial and temporal energy buffer. By way of the

(C) The Author(s). 2020 Open Access This article is licensed under a Creative Commons Attribution 4.0 International License, which permits use, sharing, adaptation, distribution and reproduction in any medium or format, as long as you give appropriate credit to the original author(s) and the source, provide a link to the Creative Commons licence, and indicate if changes were made. The images or other third party material in this article are included in the article's Creative Commons licence, unless indicated otherwise in a credit line to the material. If material is not included in the article's Creative Commons licence and your intended use is not permitted by statutory regulation or exceeds the permitted use, you will need to obtain permission directly from the copyright holder. To view a copy of this licence, visit http://creativecommons.org/licenses/by/4.0/ The Creative Commons Public Domain Dedication waiver (http://creativecommons.org/publicdomain/zero/1.0/) applies to the data made available in this article, unless otherwise stated in a credit line to the data. 
phosphorylated analogue phosphocreatine (PCr) and creatine kinase (CK) it transfers high energy groups from mitochondria to sites of consumption and regenerates ATP from ADP.

Maternal Cr biosynthesis and metabolism seem to be critical in pregnancy $[3,4]$, as fetal growth requires increased energy requirements, metabolic adaptations and specific nutritional needs for energy accrual. The state of the art literature on the topic currently includes preclinical studies and ongoing work in healthy human pregnancies. Recently, it has been demonstrated that the human placental homogenates are able to synthesize $\mathrm{Cr}$ [5] in addition to transferring amino acids, glucose, and oxygen to the fetus. Maternal $\mathrm{Cr}$ levels have been associated with fetal growth in a large cohort of healthy women, as reported by Dickinson and colleagues [4]. Furthermore, an increased demand for $\mathrm{Cr}$ during pregnancy was described in the spiny mouse animal model [3]. Therefore, it is conceivable that pregnant AGAT-d women are more susceptible to a $\mathrm{Cr}$ deficit due to energy demands of the fetus. In the AGAT deficiency mouse model [6] the homozygous knockout mice were unable to reproduce and to date no children from patients with AGAT deficiency have been reported.

This case report presents, for the first time, the pregnancy of a woman with AGAT-d and the challenges posed in the management of her treatment with oral $\mathrm{Cr}$ to ensure optimal conditions for both the mother and her fetus. The clinical management was accomplished by correcting the maternal $\mathrm{Cr}$ intake according to clinical and biochemical evidence.

\section{Case Presentation}

\section{Patient}

A 22-year-old AGAT-d patient informed us about her pregnancy at 11 weeks of fetal gestational age (GA), confirmed by earlier ultrasonographic examination (at 6 and 11 weeks GA).

At the age of six a diagnosis showed she was carrying a homozygous mutation in the GATM gene [c.446 g > A, p.(W149X)] [7] and since then had been administered high doses of $\mathrm{Cr}$ monohydrate dissolved in water (Galeno srl, Italy) with successful management results. Regular and long-term follow up had been maintained over the years by monitoring urinary, plasma and brain $\mathrm{Cr}$ levels [8]. Briefly, blood and morning urine samples were obtained after an overnight fasting period before taking the first dose of $\mathrm{Cr}$. To analyze plasma samples, the blood collected in EDTA tubes was centrifuged for $15 \mathrm{~min}$ at $1800 \mathrm{rcf}$ and the plasma separated; $200 \mu \mathrm{l}$ of plasma or urine were analyzed as described [9].

In the last examination 10 months before her pregnancy, plasma and urinary $\mathrm{Cr}$ values were $59.4 \mu \mathrm{mol} / \mathrm{L}$ (normal values: $18-141 \mu \mathrm{mol} / \mathrm{L}$ ) and $789.6 \mu \mathrm{mol} / \mathrm{L}$ (normal values: $200-5500 \mu \mathrm{mol} / \mathrm{L}$ ), respectively, and the daily $\mathrm{Cr}$ dose was $2 \mathrm{~g}$; brain $\mathrm{Cr}$ was stable around $90 \%$ of normal. However, through the long-term follow-up of the patient, we observed considerable fluctuations in $\mathrm{Cr}$ concentrations reflecting her low compliance and selfadjustment of her daily dose in order to lose weight. Her weight at the beginning of pregnancy was of $78 \mathrm{~kg}$ with a BMI of 26.67 (weight $/ \mathrm{h}^{2}$ ). The patient was omnivorous with great preference for meat-rich foods.

\section{Diagnostic assessment and therapeutic intervention}

During pregnancy, the patient underwent routine laboratory and sonographic tests as recommended by typical pregnancy guidelines. The first examination for urinary and plasma $\mathrm{Cr}$ concentrations was at $11+5$ weeks + days $(\mathrm{w}+\mathrm{d})$ of GA; subsequent examinations were scheduled at 15, 20, 27 and 36 weeks of gestation, with the possibility of reducing the interval between examinations, if necessary. Samples were sent by courier to our laboratory within $24 \mathrm{~h}$ of collection, kept on ice, and analysed on the same day of delivery. Analyses of urinary and plasma $\mathrm{Cr}$ were performed by GC/MS [9]; the analysis of creatinine $(\mathrm{Crn})$ was performed by enzymatic assay (Sentinel Diagnostics, Italy).

The patient was advised to strictly adhere to the $\mathrm{Cr}$ supplementation at prescribed dosages ( $2 \mathrm{~g} /$ day).

GATM sequencing of her husband found that he was homozygous for the normal alleles of the GATM gene.

\section{Follow-up and treatment}

Routine analyses results were all within the normal range for pregnancy (full blood count, liver and renal function, glucose load test); in particular, glycemia ranged from 88 to $81 \mathrm{mg} / \mathrm{dl}$ and no gestational hypertension was reported. Her body weight gain throughout the pregnancy was $20 \mathrm{~kg}$ and at delivery she weighed $98 \mathrm{~kg}$ with a BMI of 33.5 (weight $/ \mathrm{h}^{2}$ ).

Plasma $\mathrm{Cr}$ concentrations slowly decreased during the first weeks of gestation, ranging from $66.8 \mu \mathrm{mol} / \mathrm{L}$ at $11+5(\mathrm{w}+\mathrm{d})$ to $53.1 \mu \mathrm{mol} / \mathrm{L}$ at 15 weeks GA. Conversely, urinary $\mathrm{Cr}$ at that time was $279.5 \mu \mathrm{mol} / \mathrm{L}$, about one third of the value recorded at preconception $(789.6 \mu \mathrm{mol} / \mathrm{L})$. Routine ultrasound control at $20 \mathrm{w} \mathrm{GA}$ highlighted reduced fetal brain development as indicated by head circumference $(\mathrm{HC})$ value of $176.2 \mathrm{~mm}(<2.3$ centile) [10]. At $20+3(w+d)$ GA a further decline in plasma $\mathrm{Cr}$ concentrations with value of $30.4 \mu \mathrm{mol} / \mathrm{L}$ was observed (Table 1); urinary $\mathrm{Cr}$ value was $286.4 \mu \mathrm{mol} / \mathrm{L}$. To avoid the risk of microcephaly, the $\mathrm{Cr}$ dose was promptly increased to $3 \mathrm{~g} /$ day; at $21+3(\mathrm{w}+\mathrm{d}) \mathrm{GA}$ an increase of plasma Cr level was observed $(45.5 \mu \mathrm{mol} / \mathrm{L})$, while urinary $\mathrm{Cr}$ value still remained low $(297.9 \mu \mathrm{mol} /$ L). After 5 weeks an increase of $\mathrm{Cr}$ levels in both plasma and urine (76.2 and $5533 \mu \mathrm{mol} / \mathrm{L}$, respectively) were 
Table 1 Fetal parameters and maternal biochemical parameters

\begin{tabular}{|c|c|c|c|c|c|c|c|c|c|}
\hline$\overline{G A}$ & CRL & BPD & $\mathrm{HC}$ & $A C$ & $\mathrm{FL}$ & $\begin{array}{l}\text { Maternal } \\
\text { plasma } \mathrm{Cr}\end{array}$ & $\begin{array}{l}\text { Maternal } \\
\text { urine } \mathrm{Cr}\end{array}$ & $\begin{array}{l}\text { Maternal } \\
\text { urine } \mathrm{Crn}\end{array}$ & $\begin{array}{l}\text { Maternal } \\
\text { Cr dose }\end{array}$ \\
\hline$w+d$ & $\begin{array}{l}\mathrm{mm} \\
\text { (centiles) }\end{array}$ & $\begin{array}{l}\mathrm{mm} \\
\text { (centiles) }\end{array}$ & $\begin{array}{l}\mathrm{mm} \\
\text { (centiles) }\end{array}$ & $\begin{array}{l}\text { mm } \\
\text { (centiles) }\end{array}$ & $\begin{array}{l}\mathrm{mm} \\
\text { (centiles) }\end{array}$ & $\begin{array}{l}\mu \mathrm{mol} / \mathrm{L} \\
\text { n.v.: } 18-141\end{array}$ & $\begin{array}{l}\mu \mathrm{mol} / \mathrm{L} \\
\text { n.v.: } 200-5500\end{array}$ & $\mathrm{mmol} / \mathrm{L}$ & g/day \\
\hline 0 & - & - & - & - & - & 59.4 & 789.6 & 7.1 & 2 \\
\hline $11+5$ & $\begin{array}{l}50.8 \\
(35)\end{array}$ & - & - & - & - & 66.8 & 678.2 & 12.2 & 2 \\
\hline $20+3$ & & $\begin{array}{l}47.7 \\
(16)\end{array}$ & $\begin{array}{l}176.2 \\
(<2.3)\end{array}$ & $\begin{array}{l}148.4 \\
(13)\end{array}$ & $\begin{array}{l}32.5 \\
(16)\end{array}$ & 30.4 & 286.4 & 6.1 & 2 \\
\hline $26+5$ & & $\begin{array}{l}66.1 \\
(37)\end{array}$ & $\begin{array}{l}234.6 \\
(3)\end{array}$ & $\begin{array}{l}208.6 \\
(10)\end{array}$ & $\begin{array}{l}48.7 \\
(25)\end{array}$ & 76.2 & 5533 & 3.7 & 3 \\
\hline $34+5$ & & & & & & 85.0 & 10,806 & 17.1 & 3 \\
\hline
\end{tabular}

$G A(W+d)$ Gestational age (Weeks + days), CRL crown rump length, BPD biparietal diameter, HC Head circumference, $A C$ abdominal circumference, FL femoral length, $\mathrm{Cr}$ creatine, $\mathrm{Crn}$ creatinine, n.v. normal values. In the brackets the centiles for the fetus growth

observed; the fetal head growth did not show any further decrease in size as compared to the normal range for $\mathrm{GA}$, but rather showed an increasing trend (HC $234.6 \mathrm{~mm}$, 3rd centile). During the last biochemical examination before delivery, at $34+5(\mathrm{w}+\mathrm{d}) \mathrm{GA}$, a further increase of $\mathrm{Cr}$ concentration was detected (Table 1). At that time, urinary $\mathrm{Cr}$ and $\mathrm{Crn}$ values rose markedly to $10,806 \mu \mathrm{mol} / \mathrm{L}$ and $17.1 \mu \mathrm{mmol} / \mathrm{L}$, respectively (Table 1). Plasma and urine GAA concentrations in the mother were always under the normal values or undetectable.

At 35 weeks the patient delivered a male newborn by planned caesarean section, weighing $2450 \mathrm{~g}$ (25th centile), with a length of $49 \mathrm{~cm}$ (25th centile) and $\mathrm{HC}$ of $32 \mathrm{~cm}$ (10th centile); APGAR score was 8-9. The newborn plasma and urinary concentrations of $\mathrm{Cr}$ were 56.4 and $103 \mu \mathrm{mol} / \mathrm{L}$, respectively. The guanidinoacetic acid (GAA) values in the infant plasma and urine were both low $(0.15$ and $17.2 \mu \mathrm{mol} / \mathrm{L}$, respectively; GAA reference range: $0.22-3.14 \mu \mathrm{mol} / \mathrm{L}$ in plasma, $56-698 \mu \mathrm{mol} / \mathrm{L}$ in urine, respectively). He was breastfed for 4 months during which the mother continued taking $3 \mathrm{~g} /$ day of $\mathrm{Cr}$; at that time the plasma $\mathrm{Cr}$ of the child was $49.4 \mu \mathrm{mol} / \mathrm{L}$, the $\mathrm{Cr}$ on brain MRS was normal as well as brain MRI.

The boy reached normal developmental milestones; his weight and height remained at 25th centiles. At four months his sucking was normal as were his muscle tone and strength; the general movements examination (GMs) was also normal (present fidgety movements). At 12 months of age, the plasma and urinary $\mathrm{Cr}$ of the baby increased to 67.7 and $369.7 \mu \mathrm{mol} / \mathrm{L}$; the plasma and urinary GAA concentrations were $0.56 \mu \mathrm{mol} / \mathrm{L}$ and $250.2 \mu \mathrm{mol} / \mathrm{L}$, respectively. The child's psychomotor development was normal (Bayley III) and auxological data, including $\mathrm{HC}$, were at the 25th centile. After 4 months of breastfeeding, the mother, of her own accord, decided to reduce her $\mathrm{Cr}$ supplementation, returning to the dose prior to her pregnancy of $2 \mathrm{~g}$ daily, because of weight gain.

\section{Discussion}

This report, the first presenting the course of a pregnancy of a woman carrying a homozygous mutation in GATM gene who had always been fully dependent on an external $\mathrm{Cr}$ supply since an AGAT-d diagnosis at 6 years, provides additional evidence that $\mathrm{Cr}$ may be important during pregnancy. The most relevant findings were (i) decreased levels of urinary and, to a lesser extent, plasma $\mathrm{Cr}$ concentrations in the first months of fetal gestation; (ii) reduction of fetal $\mathrm{HC}$ below 2.3 centile detected at 20 weeks GA and (iii) partial recovery of auxological parameters of the fetus once the Cr dose administered to the mother had been increased.

The clinical data reported here must be carefully interpreted, because the observed results may have been biased by the study limitations. The limitations included full dependency of the mother on an external Cr supply, some difficulties in communication between medical staff and the patient, and the treatment of the patient at home due to the considerable distance between her home and our hospital.

$\mathrm{Cr}$ homeostasis during pregnancy changes in both animal models and in humans. Studies with spiny mice have shown decreased renal excretion between middle and late gestation, and modifications of the expression of synthetic enzymes and transporter [3]. In healthy women, Dickinson et al. [4] observed that plasma $\mathrm{Cr}$ concentrations were stable across gestation whereas urine levels decreased significantly at 18 weeks GA. By contrast, Pinto et al. [11] reported a decrease in both plasma $\mathrm{Cr}$ and $\mathrm{Crn}$ in the first trimester only, and no correlations between plasma and urinary $\mathrm{Cr}$ and $\mathrm{Crn}$ concentrations. In our patient, plasma $\mathrm{Cr}$ always remained within the normal range over the pregnancy, 
while urinary $\mathrm{Cr}$ concentrations quickly fell within a few weeks reaching the lowest normal values. The $\mathrm{Cr}$ decrease in plasma and more markedly in urine between 11 and 20 weeks may have been due to fetal demand, given the maternal compliance which was consistently monitored starting from the 11th week. Whether the decrease of $\mathrm{Cr}$ in body fluids is due to alterations in its distribution between plasma and tissues, or to a reduced absorption of $\mathrm{Cr}$ supply across the gut during gestation, or even to an increased fetal demand that drains $\mathrm{Cr}$ from the mother, is currently unknown. From this finding, urinary $\mathrm{Cr}$ concentrations in pregnant women could be considered a more suitable marker to monitor fetal requirements for his/her optimal growth. This is consistent with the observations of Dickinson et al. who reported a positive association of urinary $\mathrm{Cr}$ levels with birthweight and birth length [4].

Furthermore, $\mathrm{Cr}$ is crucial for brain development, concentrations of which gradually increase in a normal fetal brain during GA as energy needs and cerebral structures evolve and double at the end of pregnancy [12]. Recent studies demonstrate that normal human placental homogenates can endogenously synthesise $\mathrm{Cr}$, and abundant AGAT protein was detected in the human placenta at term [5]. Moreover, the mRNA for the $\mathrm{Cr}$ transporter (SLC6A8) has been detected in the first trimester chorionic villus biopsies (CVBs) and in placental samples [13], suggesting that the active transport of $\mathrm{Cr}$ into placental cells is in place from early gestation. Based on this speculation, the $\mathrm{Cr}$ transporter seems to be essential for the development of the fetus, representing the only way to provide him with the energy necessary for development, at least until his AGAT and GAMT are properly functioning. Further studies in this area would be beneficial so as to acquire greater knowledge regarding the time at which the $\mathrm{Cr}$ synthesis is fully developed in the fetus and the contribution of placenta in providing adequate $\mathrm{Cr}$ supply for fetal development. Nevertheless, the inability of our patient to synthesize $\mathrm{Cr}$ sufficiently, the still unknown role of the fetal placental tissue (which may have the enzymes for synthesis) and the high energy demands of the developing fetus not balanced by the amount of $\mathrm{Cr}$ absorbed considering her daily meat intake, led us to increase the maternal $\mathrm{Cr}$ supply. Based on our previous experience in patients with AGAT-d, the $\mathrm{Cr}$ dose was empirically raised to $3 \mathrm{~g} /$ day after the test at $20+3 \mathrm{GA}$, followed by a parallel increase of plasma $\mathrm{Cr}$ after 1 week [8]. One week before delivery the concentrations of $\mathrm{Cr}$ and $\mathrm{Crn}$ in the patient increased further, without signs of renal toxicity. These high values were not surprising, because we found that the mother had had similarly high values after $\mathrm{Cr}$ supplementation at 200 and at $100 \mathrm{mg} / \mathrm{Kg}$. When this occurred over the years the $\mathrm{Cr}$ dose was gradually reduced to $2 \mathrm{~g}$ /day while ensuring, at the same time, that both the plasma and brain $\mathrm{Cr}$ concentrations were within the normal range [8] and adverse effects were avoided. Even on those occasions however, her urinary $\mathrm{Cr}$ and $\mathrm{Crn}$ levels sometimes rose to similar high values. Then again, it was difficult to predict the ratio of $\mathrm{Cr}$ absorbed after the increased dosage because it could potentially vary during pregnancy. In addition, various other factors could have contributed to the increase of the $\mathrm{Cr}$ and $\mathrm{Crn}$ levels observed, such as reduced hydration, alterations in the renal function in the final months of pregnancy, changes in hormonal metabolism and dietary intake, and placental changes in $\mathrm{Cr}$ transfer near birth [13]. As the $\mathrm{Cr}$ levels increased in the biological fluids of the patient, some parameters of fetal growth increased or stabilised, with the only exception of abdominal circumference (AC,10th centile), which decreased over the same time period. In particular, the effects of the increase in the $\mathrm{Cr}$ dosage on auxological parameters of the fetus were quickly evident, as had already been observed in the mother at diagnosis a few months after starting the $\mathrm{Cr}$ supplementation [8].

The GAA levels in both the plasma and urine of the one day old newborn were detectable but below the normal range, showing that he was already able to synthesize $\mathrm{Cr}$ on his own, despite his heterozygous status for GATM, since GAA could not come from maternal supply due to the undetectable levels in her plasma. The GAA concentrations increased during his first year reaching normal values similar to those in adults heterozygous for AGAT-d, where the plasma concentrations of GAA are not dissimilar from those of the homozygous for the normal alleles of GATM. Conversely, plasma $\mathrm{Cr}$ levels were normal at 1 day of birth, presumably for the partial contribution of $\mathrm{Cr}$ from the mother, while the concentrations in urine were low in the first day of life, reaching normal levels after 1 year. In the spiny mouse, a precocious species considered to be a reliable animal model to study the fetal development in humans, a limited capacity for endogenous $\mathrm{Cr}$ synthesis until late in pregnancy has been observed [5]. It could be supposed that in the first days of life the machinery needed for $\mathrm{Cr}$ synthesis does not function to capacity, and the GAA produced is quickly transformed into $\mathrm{Cr}$ to replenish the $\mathrm{Cr}$ pool in tissues, limiting its loss through the kidneys. Unfortunately, our data does not allow for the possibility of specifying the GA when the $\mathrm{Cr}$ metabolic pathway is fully developed.

\section{Conclusions}

Cr likely plays an important role in pregnancy, in particular, when the mother is dependent on an external supply, as for AGAT-d patients. The rapid decline in urinary $\mathrm{Cr}$ in our AGAT-d patient between 11 and 21 
weeks gestation seems to reflect the needs of the fetus and suggests that an early increase of $\mathrm{Cr}$ supplementation would be advantageous. From these data, however, it cannot be stated if a higher $\mathrm{Cr}$ dose or an earlier supplementation would have avoided the slight growth delay observed in the fetus.

\section{Abbreviations}

Cr: Creatine; AGAT-d: Arginine:Glycine Amidino-Transferase deficiency; GAMT: Guanidinoacetate methyltransferase; GA: Gestational age; Crn: Creatinine; w+d: Weeks+ days; GAA: Guanidino acetic acid; CRL: Crown rump length; BPD: Biparietal diameter; HC: Head circumference; AC: Abdominal circumference; FL: Femoral length

\section{Acknowledgements}

A special thanks to Ailish Lynam for reviewing the English in the paper and to the patient for allowing us to present her case.

\section{Authors' contributions}

MGA, RB, FS conceived the study. MGA carried out the biochemical assays. $\mathrm{RB}$ and FS monitored the patient. MGA, RB, FS wrote the manuscript. GC supervised the study. All authors revised the manuscript and agreed to the final content.

\section{Funding}

No specific funding was received for this study; the costs incurred for the biochemical tests and the English review were covered by the financial support received from the Italian Ministry of Health Ricerca Corrente, and the $5 \times 1000$ voluntary contributions.

\section{Availability of data and materials}

Datasets used and /or analysed in the current study are available from the corresponding author upon reasonable request.

\section{Ethics approval and consent to participate}

The research was part of a more general project on the treatment of primary $\mathrm{Cr}$ defects approved by the Stella Maris Institute Ethical Committee. Informed written consent was obtained from the patient, before starting the $\mathrm{Cr}$ supplementation,

\section{Consent for publication}

Written consent was obtained from the patient for the publication of the case and the use of data.

\section{Competing interests}

No competing interests to disclose.

\section{Author details}

'Department of Developmental Neuroscience, IRCCS Stella Maris Foundation, Via dei Giacinti 2, 56128 Calambrone - Pisa, Italy. ${ }^{2}$ Department of Clinical and Experimental Medicine, University of Pisa, Pisa, Italy.

Received: 25 April 2019 Accepted: 19 August 2020

Published online: 03 September 2020

\section{References}

1. Stromberger C, Bodamer O, Stockler-Ipsiroglu S. Clinical characteristics and diagnostic clues in inborn errors of creatine metabolism. J Inher Metab Dis. 2003;26:299-308

2. Stockler-Ipsiroglu S, Apatean D, Battini R, DeBrosse S, Dessoffy K, Edvardson $S$, et al. Arginine:glycine amidinotransferase (AGAT) deficiency: Clinical features and long term outcomes, in 16 patients diagnosed worldwide. Mol Genet Metab. 2015;116:252-9.

3. Ellery SJ, LaRosa DA, Kett MM, Della Gatta PA, Snow RJ, Walker DW, et al. Maternal creatine homeostasis is altered during gestation in the spiny mouse: is this a metabolic adaptation to pregnancy? BMC Pregnancy Childbirth. 2015:15:92-100

4. Dickinson H, Davies-Tuck M, Ellery SJ, Grieger JA, Wallace EM, Snow RJ, et al. Maternal creatine in pregnancy: a retrospective cohort study. BJOG. 2016; 123:1830-8.
5. Ellery SJ, Della Gatta PA, Bruce CR, Kowalski GM, Davies-Tuck M, Mockler JC, et al. Creatine biosynthesis and transport by the term human placenta. Placenta. 2017;52:86-93.

6. Choe C, Nabuurs C, Stockebrand MC, Neu A, Nunes P, Morellini F, et al. Larginine:glycine amidinotransferase deficiency protects from metabolic syndrome. Hum Mol Genet. 2013;22:110-23.

7. Item CB, Stöckler-Ipsiroglu S, Stromberger C, Mühl A, Alessandrì MG, Bianchi $M C$, et al. Arginine:glycine amidinotransferase deficiency: the third inborn error of creatine metabolism in humans. Am J Hum Genet. 2001;69:1127-33.

8. Battini R, Alessandrì MG, Casalini C, Casarano M, Tosetti M, Cioni G. Fifteenyear follow-up of Italian families affected by arginine glycine amidinotransferase deficiency. Orphanet J Rare Dis. 2017;12:2

9. Alessandrì MG, Celati L, Battini R, Casarano M, Cioni G. Gas chromatography/ mass spectrometry assay for arginine:glycine-amidinotransferase deficiency. Anal Biochem. 2005:343:356-58.

10. Hadlock FP, Deter RL, Harrist RB, Park SK. Fetal head circumference: relation to menstrual age. Am J Roentgenol. 1982;138:649-53.

11. Pinto J, Barros AS, Domingues MRM, Goodfellow BJ, Galhano E, Pita C, et al. Following Healthy Pregnancy by NMR Metabolomics of Plasma and Correlation to Urine. J Proteome Res. 2015:14:1263-74.

12. Evangelou IE, du Plessis AJ, Vezina G, Noeske R, Limperopoulos C Elucidating Metabolic Maturation in the Healthy Fetal Brain Using 1H-MR Spectroscopy. AJNR. 2016;37:360-6.

13. Ellery SJ, Murthi P, Davies-Tuck ML, Della Gatta PA, May AK, Kowalski GM, et al. Placental creatine metabolism in cases of placental insufficiency and reduced fetal growth. Mol Hum Reprod. 2019;25:495-505.

\section{Publisher's Note}

Springer Nature remains neutral with regard to jurisdictional claims in published maps and institutional affiliations.

\section{Ready to submit your research? Choose BMC and benefit from:}

- fast, convenient online submission

- thorough peer review by experienced researchers in your field

- rapid publication on acceptance

- support for research data, including large and complex data types

- gold Open Access which fosters wider collaboration and increased citations

- maximum visibility for your research: over $100 \mathrm{M}$ website views per year

At BMC, research is always in progress.

Learn more biomedcentral.com/submission 